\title{
Efficiency - Profitability Mapping of Shipping and Marine Transportation Companies: Evidence from Indonesia
}

\author{
Titi Dewi Warninda
}

Faculty of Economics and Business, Syarif Hidayatullah State Islamic University Jakarta, Indonesia E-mail:warninda@yahoo.com

\author{
Doi:10.5901/mjss.2015.v6n5s5p230
}

\section{Abstract}

In supporting the maritime economy as the backbone of Indonesian economy, shipping and marine transportation companies should increase their performances. This research aims to analyze efficiency-profitability mapping of Indonesian shipping and marine transportation companies using efficiency-profitability matrix. This research uses Return on Assets (ROA) as profitability proxy and Data Envelopment Analysis for the measurement of efficiency (overall technical efficiency, pure technical efficiency, and scale efficiency). The results of this research show that not all of the technically efficient shipping and marine transportation companies are scale efficient. This research also finds that not all of the companies that have high profitability are also having high efficiency. Some companies are efficient but still make less profit because they are in the dog quadrant. Some companies are included in the Sleeper quadrant and should improve their management. However, most of the companies are included in the Star quadrant, means that most of the companies have high efficiency and profitability. The results of this research show that it's important for to the shipping and marine transportation companies to increase their efficiency in order to have higher profitability.

Keywords: efficiency, profitability, data envelopment analysis

\section{Introduction}

The government of Indonesia has a plan to make maritime economy as the backbone of Indonesian economy. This plan should be followed by increasing the developments in maritime sectors. Shipping and marine transportation sector become one of maritime sectors that should be developed for increasing its performance in giving marine transportation services and supporting the maritime economy.

Currently, there are several shipping and marine transportation companies listed on the Indonesian Stock Exchange. Listed companies should have good performance to maximize their shareholders wealth. However, the performance of listed shipping and marine transportation companies for the last three years is not quite satisfactory. The average profitability of the shipping and marine transportation companies indicated by Return on Assets (ROA) in 2011 was $-5.7 \%$, decreased to $-8.8 \%$ in 2012 , and became $2.8 \%$ in 2013. Average profitability of the shipping and marine transportation companies in 2013 became positive but some of the companies still have negative profitability.

The unsatisfactory performance of the Indonesian listed shipping and marine transportation companies becomes the background of this efficiency-profitability mapping research. Based on Noor and Ahmad (2012), there is a positive correlation between efficiency and profitability. It means that Decision Making Unit (DMU) which has high level of efficiency will have high profitability. Meanwhile, according to Abu-Alkheil, Burghof, and Khan (2012), not all of Decision Making Units (DMUs) which have high efficiency are also having high profitability. Research on efficiency and profitability of Indonesian listed shipping and marine transportation companies will determine whether there are a lot of inefficient shipping and marine transportation companies and whether the inefficient companies are also having lower profitability than the more efficient companies. So, there will be a map about efficiency-profitability of Indonesian listed shipping and marine transportation companies. The analysis of efficiency and profitability will be useful for the development of the shipping and marine transportation companies and supporting the maritime economy.

To measure profitability, this research uses Return on Assets (ROA), while the efficiency measurement uses nonparametric approach that is Data Envelopment Analysis (DEA). DEA is a linear programming method that is used to measure the efficiency of a Decision Making Unit (DMU). DEA formed a standard that a DMU is efficient compared to other inefficient DMU (Said, 2013). The DEA model uses Constant Returns to Scale (CRS) and Variable Returns to Scale (VRS) assumptions. These assumptions are used to determine the overall technical efficiency, technical efficiency without scale efficiency (pure technical efficiency), and whether the inefficiency is caused by companies that is not in the 
optimum scale yet (scale inefficiency).

Some previous researches have studied about efficiency of shipping companies as follows. Gutiérrez, et al., (2014) studied about the efficiency of international Container Shipping Lines (CSL) using Data Envelopment Analysis. Panayides, et al., (2011) examined the relative market and operating efficiencies of firms in the three key sectors of the shipping industry, i.e. dry, wet and container shipping. The study of Wang, et al., (2014) was about market and operating efficiencies of international shipping companies listed in Bloomberg Shipping Indices. Meanwhile, Bang, et al., (2012) have done research on the relative efficiency of liner shipping companies in terms of operational and financial performance and further investigates the impact of strategic and operational management on efficiency performance using a two-stage Data Envelopment Analysis (DEA) approach. Some of previous researches show that shipping companies have high efficiency, but some of them indicate that shipping companies have low efficiency. This research investigates further the efficiency of shipping and marine transportation companies and the relationship between efficiency and profitability using efficiency-profitability matrix.

This research aims to analyze profitability and efficiency of listed shipping and marine transportation companies in Indonesia. Using efficiency-profitability matrix, this research will show whether shipping and marine transportation companies which have high efficiency are also having high profitability. The result of this research will enrich the literature about efficiency and profitability of shipping and marine transportation companies and contribute in the development of maritime economy as the backbone of Indonesian economy.

Differences of this research over previous researches are as follows. First, this research measures overall technical efficiency, pure technical efficiency, and scale efficiency of Indonesian listed shipping and marine transportation companies using Data Envelopment Analysis (DEA). Second, this research gives analysis of efficiency-profitability mapping using efficiency-profitability matrix to analyze whether the efficient companies are also having high profitability.

\section{Methodology}

\subsection{Profitability and Efficiency Measurements}

This research uses data from 2013 financial reports of Indonesian listed shipping and marine transportation companies to get recent analysis about Indonesian listed shipping and marine transportation companies efficiency and profitability. It also uses data from 2012 and 2011 financial reports for robustness test. There are seventeen listed shipping and marine transportation companies in 2013, but because of incomplete data, this research only uses fourteen companies as samples. The proxy of profitability is Return on Assets (ROA). This research uses Data Envelopment Analysis (DEA) to measure technical efficiency, pure technical efficiency, and scale efficiency of Indonesian listed shipping and marine transportation companies. DEA is a linear programming method that is used to measure the efficiency of a Decision Making Unit (DMU). DEA forms a standard that a DMU is efficient compared to other inefficient DMU (Said, 2013).

The measurement of overall technical efficiency uses Constant Returns to Scale (CRS) model. CRS model or CCR (Charnes, Cooper, and Rhodes) model is a DEA model that was first introduced by Charnes, et al., in 1978. CRS model uses constant returns to scale and optimal scale operations assumptions. This model is a weighted ratio of output and input. This would indicate that the more output generated by a particular input, the more efficient a DMU. CRS model measures the overall technical efficiency of a DMU. Overall technical efficiency is a combination of pure technical efficiency and scale efficiency.

The measurement of pure technical efficiency uses Variable Returns to Scale (VRS) model. VRS models or BCC (Banker, Charnes, and Cooper) model was made by Banker, Charnes, and Cooper in 1984 and was an improvement of CRS model by adding variable returns to scale assumptions. VRS model provides a measurement of pure technical efficiency, which is technical efficiency without scale efficiency.

Scale efficiency can be calculated using the ratio between overall technical efficiency and pure technical efficiency. Which is the ratio between CRS technical efficiency and VRS technical efficiency. The difference between overall technical efficiency and pure technical efficiency will show that the DMU is not scale efficient.

DEA-model in this research consists of three inputs and one output. This research uses total fixed assets, operating costs, and number of employees for the inputs, as used by Yu, et al., (2012). The output is operating revenue, as used by Nanka-Bruce (2011). So, this research uses non-negativity variables.

\subsection{Efficiency-Profitability Matrix}

Shipping and marine transportation companies efficiency-profitability mapping uses efficiency-profitability matrix that has 
a structure such as the product portfolio matrix (Alkheil, et al.,, 2012). Efficiency-profitability matrix consists of four quadrants as follows:

1. Star quadrant : consists of a DMU which has a high level of profitability and efficiency, which is the best DMU.

2. Sleeper quadrant : consists of a DMU which has high profitability but low efficiency, which is not a good sign from long-term perspective. The high profitability is due to primarily more favorable environmental conditions than good management.

3. Question Mark quadrant : consist of a DMU which has a low level of profitability and efficiency. This DMU has the potential to achieve higher level of profitability and efficiency.

4. Dog quadrant : consists of a DMU which has a low level of profitability but high efficiency. The DMU is efficient but still make less profit. The DMU operates efficiently but has low profitability due to unfavorable environment.

Table 1: Efficiency-Profitability Matrix

\begin{tabular}{|c|cc|}
\hline \multicolumn{2}{|c|}{ Profitability } \\
\hline High & Sleeper & Star \\
Low & Question Mark & Dog \\
Efficiency & Low & High \\
\hline
\end{tabular}

Star quadrant consists of shipping and marine transportation companies that have high efficiency and profitability. Dog quadrant consists of companies that have high level of efficiency but low profitability. Sleeper quadrant consists of companies that have low level of efficiency but have high profitability. While Question Mark quadrant consists of companies that have low efficiency and profitability.

The criteria for high or low level of profitability and efficiency is based on the mean value of the overall profitability and efficiency data (Tsolas, 2011). Company which has a higher profitability or efficiency than the mean value or equal with the mean value is a company with high level of profitability or efficiency. While company which has a lower profitability or efficiency than the mean value is a company with low level of profitability or efficiency.

\section{Empirical Results}

The results of profitability (ROA) and efficiency (overall technical efficiency, pure technical efficiency, and scale efficiency) measurements using 2013 data of the shipping and marine transportation companies are as follows. Average profitability of the companies is $2.8 \%$. Only nine companies that have profitability level above average and two companies have negative profitability. Average efficiency level from overall technical efficiency is 0.942 . Only eight companies that have overall technical efficiency level above average. Meanwhile, average efficiency level from pure technical efficiency and scale efficiency are 0.972 and 0.970 , respectively. Eleven companies have pure technical efficiency level above average and eight companies have scale efficiency level above average.

Shipping and marine transportation companies profitability and efficiency table shows that not all of the companies that have high efficiency are also having high profitability. It also shows that not all of the companies that have technical efficiency are also having scale efficiency. The number of the technically efficient companies is more than the number of scale efficient companies.

Only six shipping and marine transportation companies (PT Berlian Laju Tanker Tbk (BLTA), PT Mitra Bahtera Segara Sejati Tbk (MBSS), PT Logindo Samudra Makmur Tbk (LEAD), PT Wintermar Offshore Marine Tbk (WINS), PT Pelayaran Tempuran Mas Tbk (TMAS) and PT Samudera Indonesia Tbk (SMDR)) are efficient in all types of efficiency, indicates that those companies have technical and scale efficiency. Meanwhile, four other companies (PT Pelayaran Nelly Dwi Putri Tbk (NELY), PT Indo Straits Tbk (PTIS), PT Pelayaran Nasional Bina Buana Raya Tbk (BBRM), and PT Trada Maritime Tbk (TRAM)), are just efficient in pure technical efficiency, indicates that those companies are not scale efficient. All companies that are scale efficient are also technically efficient. 
Table 2: Profitability and Efficiency of the Shipping and Marine Transportation Companies

\begin{tabular}{|c|c|c|c|c|c|}
\hline & Companies & Profitability (ROA) & Overall Technical Efficiency & Pure Technical Efficiency & Scale Efficiency \\
\hline 1 & BLTA & 0.232 & 1 & 1 & 1 \\
\hline 2 & NELY & 0.190 & 0.962 & 1 & 0.962 \\
\hline 3 & MBSS & 0.110 & 1 & 1 & 1 \\
\hline 4 & LEAD & 0.086 & 1 & 1 & 1 \\
\hline 5 & WINS & 0.064 & 1 & 1 & 1 \\
\hline 6 & TPMA & 0.062 & 0.937 & 0.98 & 0.955 \\
\hline 7 & PTIS & 0.045 & 0.91 & 1 & 0.91 \\
\hline 8 & TMAS & 0.042 & 1 & 1 & 1 \\
\hline 9 & BBRM & 0.033 & 0.896 & 1 & 0.896 \\
\hline 10 & HITS & 0.018 & 0.836 & 0.853 & 0.98 \\
\hline 11 & TRAM & 0.012 & 0.96 & 1 & 0.96 \\
\hline 12 & SMDR & 0.010 & 1 & 1 & 1 \\
\hline 13 & RIGS & -0.012 & 0.793 & 0.818 & 0.97 \\
\hline 14 & APOL & -0.347 & 0.903 & 0.956 & 0.944 \\
\hline
\end{tabular}

After calculating the profitability (ROA), and efficiency based on overall technical efficiency, pure technical efficiency, and scale efficiency, the profitability and efficiency are then grouped into the high and low groups of efficiency and profitability. Efficiency-profitability mapping in the efficiency-profitability matrix based on the high and low groups of efficiency and profitability will show which company that is included in the Star quadrant, Dog quadrant, Sleeper quadrant, or Question Mark quadrant. Efficiency-profitability mapping based on 2013 data of shipping and marine transportation companies from overall technical efficiency (CRS) are as follows.

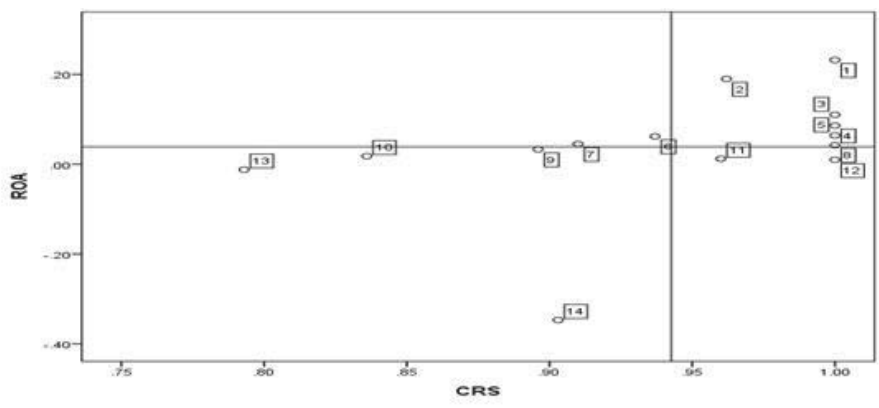

Figure 1: Efficiency-Profitability Matrix of 2013 Data from Overall Technical Efficiency

Note: the numbers on the dots show the shipping and marine transportation companies as in Table 2.

Based on efficiency-profitability matrix above, most of the shipping and marine transportation companies are included in the Star quadrant. There are six companies that are included in Star quadrant based on overall technical efficiency which are PT Berlian Laju Tanker Tbk (BLTA), PT Pelayaran Nelly Dwi Putri Tbk (NELY), PT Mitra Bahtera Segara Sejati Tbk (MBSS), PT Logindo Samudra Makmur Tbk (LEAD), PT Wintermar Offshore Marine Tbk (WINS), and PT Pelayaran Tempuran Mas Tbk (TMAS). Star quadrant consists of companies which have high level of profitability and efficiency, which are the best shipping and marine transportation companies in 2013.

Sleeper quadrant of efficiency-profitability matrix above shows that there are three shipping and marine transportation companies that are included in Sleeper quadrant from the overall technical efficiency which are PT Trans Power Marine Tbk (TPMA) and PT Indo Straits Tbk (PTIS). Sleeper quadrant consists of companies which have high profitability but low efficiency compared to other companies, means that these companies should improve their management.

Shipping and marine transportation companies that are included in Question Mark quadrant based on overall technical efficiency are PT Pelayaran Nasional Bina Buana Raya Tbk (BBRM), PT Humpuss Intermoda Transportasi Tbk (HITS), PT Rigs Tenders Indonesia Tbk (RIGS), and PT Arpeni Pratama Ocean Line Tbk (APOL). Question Mark 
quadrant consists of companies which have a low level of profitability and efficiency. These companies have the potential to achieve higher level of profitability and efficiency if they get more favorable environment and additional appropriate resources.

There are two shipping and marine transportation companies that are included in Dog quadrant from the overall technical efficiency which are PT Trada Maritime Tbk (TRAM) and PT Samudera Indonesia Tbk (SMDR). Dog quadrant consists of companies which have a low level of profitability but high efficiency. The company is efficient but still makes less profit.

Efficiency-profitability mapping based on 2013 data of shipping and marine transportation companies from pure technical efficiency (VRS) are as follows.

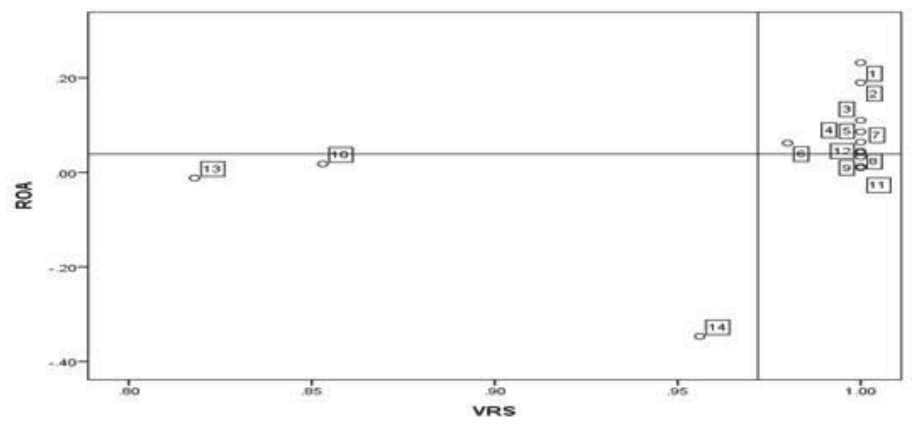

Figure 2: Efficiency-Profitability Matrix of 2013 Data from Pure Technical Efficiency

Note: the numbers on the dots show the shipping and marine transportation companies as in Table 2.

Efficiency-profitability matrix in Figure 2 above shows efficiency-profitability mapping of the shipping and marine transportation companies from pure technical efficiency (VRS). There are more companies included in the Star quadrant and less companies included in other quadrants compared to Figure 1. It means that most of the companies are having high technical efficiency and high profitability.

Efficiency-profitability mapping based on 2013 data of shipping and marine transportation companies from scale efficiency (SCALE) are as follows.

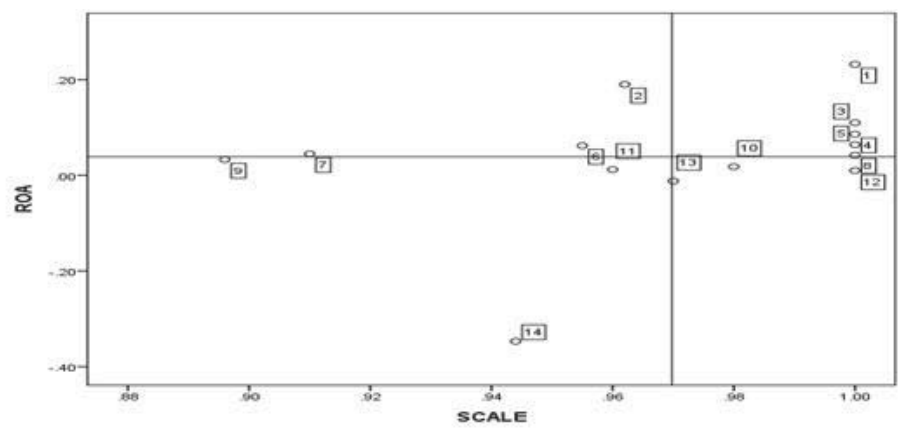

Figure 3: Efficiency-Profitability Matrix of 2013 data from Scale Efficiency

Note: the numbers on the dots show the shipping and marine transportation companies as in Table 2.

Efficiency-profitability matrix in Figure 3 above shows efficiency-profitability mapping of the shipping and marine transportation companies from scale efficiency (SCALE). Figure 3 above shows that most of the companies are included in the Star quadrant, indicates that most of the companies are having high scale efficiency and high profitability. The 
results of Figure 3 are different from Figure 2. The results show that not all of the shipping and marine transportation companies that technically efficient are also scale efficient.

\subsection{Robustness Test}

This section investigates whether the result of efficiency-profitability mapping using 2012 and 2011 data will find similar results with the mapping using 2013 data. In general, the results of efficiency-profitability mapping using 2012 and 2011 data show similar result with the analysis using 2013. Not all of the shipping and marine transportation companies that have high efficiency are also having high profitability and not all of the companies that technically efficient are also scale efficient. The results also find that most of the shipping and marine transportation companies are included in the Star quadrant or having high efficiency and profitability.

\section{Conclusions}

Based on the result and analysis of efficiency-profitability mapping of the listed shipping and marine transportation companies, not all of the companies that have high profitability are also having high efficiency. This result supports previous research by Alkheil, et al., (2012) that not all Decision Making Units (DMUs) which have high efficiency are also having high profitability.

The companies that are in the Sleeper quadrant should improve their management because they have high profitability but low efficiency. The companies that are in the Question Mark quadrant should get more favorable environment and additional appropriate resources to have higher level of profitability and efficiency. The companies that are in the Dog quadrant is efficient but still makes less profit and should get more favorable environment.

This research finds that not all of the companies that technically efficient are also scale efficient. The number of the technically efficient companies is more than the number of scale efficient companies, means that some companies should reach its optimum scale.

Most of the shipping and marine transportation companies are included in the Star quadrant, means that most of the companies have high efficiency and profitability. The results of this research show that it's important for the shipping and marine transportation companies to have higher efficiency in order to have higher profitability.

\section{References}

Alkheil, et al., (2012). Islamic commercial banking in Europe: a Cross-country and inter-Bank analysis of efficiency performance. International Business and Economics Research Journal, 11 (6), 647-676.

Bang, et al., (2012). The impact of operational and strategic management on liner shipping efficiency: a two-stage DEA approach. Maritime Policy \& Management, 39(7), 653-672.

Gutiérrez, E., Lozano, S., and Furió, S. (2014). Evaluating efficiency of international container shipping lines: A bootstrap DEA approach. Maritime Economics \& Logistics, 16(1), 55-71.

Nanka-Bruce, D. (2011). Corporate governance mechanisms and firm efficiency. International Journal of Business \& Management, 6 (5), 28-40.

Noor, M. A. and Ahmad, N. H. (2012). The determinants of world Islamic banks' efficiency: Does country income level have an impact? Journal of Islamic Economics, Banking and Finance, 8 (2), 9-44.

Panayides, et al., (2011). The relative efficiency of shipping companies. Transportation Research Part E: Logistics and Transportation Review, 47(5), 681-694.

Said, A. (2013). Risk and efficiency in the Islamic banking system: The case of selected Islamic banks in MENA region. International Journal of Economics and Financial Issues, 3 (1), 66-73.

Tsolas, I. E. (2011). Relative profitability and stock market performance of listed commercial banks on the Athens Exchange: a nonparametric approach. IMA Journal of Management Mathematics, 22, 323-342.

Wang, et al., (2014). The relative efficiency and financial risk assessment of shipping companies. Maritime Policy \& Management, 41(7), 651-666.

Yu, et. al., (2012). A study of estimating the technical efficiency of optoelectronic firms: An application of data envelopment analysis and tobit analysis. International Journal of Academic Research in Business \& Social Sciences, 2(7), 192-202. 